\title{
Microglial Amyloid- $\beta$ 1-40 Phagocytosis Dysfunction Is Caused by High-Mobility Group Box Protein-1: Implications for the Pathological Progression of Alzheimer's Disease
}

\author{
Kazuyuki Takata, ${ }^{1}$ Tetsuya Takada, ${ }^{1}$ Aina Ito, ${ }^{1}$ Mayo Asai, ${ }^{1}$ Manami Tawa, ${ }^{1}$ Yuki Saito, ${ }^{1}$ \\ Eishi Ashihara, ${ }^{1,2}$ Hidekazu Tomimoto, ${ }^{3}$ Yoshihisa Kitamura, ${ }^{1}$ and Shun Shimohama ${ }^{4}$ \\ ${ }^{1}$ Department of Clinical and Translational Physiology, Kyoto Pharmaceutical University, Misasagi, Yamashina-ku, \\ Kyoto 607-8414, Japan \\ ${ }^{2}$ Department of Molecular Cell Physiology, Kyoto Prefectural University of Medicine, Kamigyo-ku, Kyoto 602-8566, Japan \\ ${ }^{3}$ Department of Neurology, Mie University, Graduate School of Medicine, Tsu 514-8507, Japan \\ ${ }^{4}$ Department of Neurology, School of Medicine, Sapporo Medical University, S1W16, Chuo-ku, Sapporo 060-8543, Japan
}

Correspondence should be addressed to Kazuyuki Takata, kaz@mb.kyoto-phu.ac.jp

Received 30 November 2011; Accepted 24 February 2012

Academic Editor: Akio Suzumura

Copyright ( $) 2012$ Kazuyuki Takata et al. This is an open access article distributed under the Creative Commons Attribution License, which permits unrestricted use, distribution, and reproduction in any medium, provided the original work is properly cited.

In Alzheimer disease (AD) patient brains, the accumulation of amyloid- $\beta(\mathrm{A} \beta)$ peptides is associated with activated microglia. $\mathrm{A} \beta$ is derived from the amyloid precursor protein; two major forms of $\mathrm{A} \beta$, that is, $\mathrm{A} \beta 1-40(\mathrm{~A} \beta 40)$ and $\mathrm{A} \beta 1-42$ (A $\beta 42)$, exist. We previously reported that rat microglia phagocytose $\mathrm{A} \beta 42$, and high mobility group box protein 1 (HMGB1), a chromosomal protein, inhibits phagocytosis. In the present study, we investigated the effects of exogenous HMGB1 on rat microglial A $\beta 40$ phagocytosis. In the presence of exogenous HMGB1, A $\beta 40$ markedly increased in microglial cytoplasm, and the reduction of extracellular A $\beta 40$ was inhibited. During this period, HMGB1 was colocalized with $A \beta 40$ in the cytoplasm. Furthermore, exogenous HMGB1 inhibited the degradation of $A \beta 40$ induced by the rat microglial cytosolic fraction. Thus, extracellular HMGB1 may internalize with $\mathrm{A} \beta 40$ in the microglial cytoplasm and inhibit $\mathrm{A} \beta 40$ degradation by microglia. This may subsequently delay $\mathrm{A} \beta 40$ clearance. We further confirmed that in $\mathrm{AD}$ brains, the parts of senile plaques surrounded by activated microglia are composed of $\mathrm{A} \beta 40$, and extracellular HMGB1 is deposited on these plaques. Taken together, microglial $\mathrm{A} \beta$ phagocytosis dysfunction may be caused by HMGB1 that accumulates extracellularly on A $\beta$ plaques, and it may be critically involved in the pathological progression of $\mathrm{AD}$.

\section{Introduction}

Alzheimer's disease $(\mathrm{AD})$ is characterized by the deposition of amyloid- $\beta(\mathrm{A} \beta)$ plaques, accumulation of neurofibrillary tangles (NFTs), and loss of synapses and neurons in particular brain areas [1]. Experimental studies using transgenic $\mathrm{AD}$ mouse models have demonstrated that $\mathrm{A} \beta$ accelerates NFT formation $[2,3]$ and is closely associated with synaptic damage [4]. In contrast, $A \beta$ reduction in the brain by $A \beta$ immunization restores cognitive functions in transgenic $\mathrm{AD}$ mouse models [5-9] and also appears to slow cognitive decline in human $\mathrm{AD}$ patients [10]. Thus, the accumulation of $\mathrm{A} \beta$ may play a key role in the pathogenesis of $\mathrm{AD}$ [11].

$\mathrm{A} \beta$ is derived from the sequential proteolysis of amyloid precursor protein (APP) by $\beta$ - and $\gamma$-secretases and is composed of 37-43 amino acid residues because $\gamma$-secretase, which is a protein complex including presenilin (PS), generates the $\mathrm{C}$-terminal of $\mathrm{A} \beta$ with different lengths [12]. Among the variations in $A \beta, A \beta 1-40(A \beta 40)$ and $A \beta 1-42$ $(\mathrm{A} \beta 42)$ are the major species found in $\mathrm{AD}$ brains. The most predominant species deposited in $A \beta$ plaques is $A \beta 42$ [13], which is prone to aggregation [14] and indicates increased neurotoxicity [15]. On the other hand, $A \beta 40$ is the major 
soluble species; its secretion is 10 -fold more than that of A $\beta 42$ in normal brains. A previous study demonstrated that the deposition of $\mathrm{A} \beta 40$ in $\mathrm{AD}$ brains is particularly correlated with synaptic and neuronal loss [16]. Thus, lowering the concentration of $A \beta 40$ and $A \beta 42$ in the brain may serve as a disease-modifying therapy for $\mathrm{AD}$ patients.

Activated microglia accumulate on $\mathrm{A} \beta$ plaques in $\mathrm{AD}$ brains. Although microglial accumulation was initially believed to be involved in the formation of $A \beta$ plaques [17], experimental studies later demonstrated the ability of microglia to phagocytose $A \beta$ peptides $[18,19]$. In addition, we demonstrated microglial contribution in $A \beta 42$ clearance using primary cultured rat microglia [20-25]. However, it has been reported that microglial dystrophy occurs in aging human brains [26], and the age-related disability of microglial $\mathrm{A} \beta$ phagocytosis has been demonstrated experimentally [27]. Thus, the dysfunction of microglial A $\beta$ phagocytosis appears to be closely involved in the progression of AD pathology.

High-mobility group box protein 1 (HMGB1) is an abundant nonhistone chromosomal protein that is released from cells undergoing necrosis $[28,29]$. The released HMGB1 behaves like an inflammatory mediator by acting on receptor for advanced glycation end products (RAGE) and Toll-like receptors (TLRs) 2 and 4 [30, 31]. We have previously reported that HMGB1 is extracellularly associated with $\mathrm{A} \beta$ plaques in $\mathrm{AD}$ brain and is involved in the pathogenesis of $\mathrm{AD}$ as an inhibitory factor against microglial $A \beta 42$ phagocytosis by interfering with uptake $[32,33]$. However, the effect of extracellular HMGB1 on the microglial phagocytosis of $\mathrm{A} \beta 40$, but not $\mathrm{A} \beta 42$, has not been elucidated. Therefore, in the present study, we analyzed rat microglial $A \beta 40$ phagocytosis in the presence and absence of exogenous HMGB1.

\section{Materials and Methods}

2.1. Primary Culture of Rat Microglia and Drug Treatment. The primary culture experimental procedure was reviewed and approved by the Committee for Animal Research at Kyoto Pharmaceutical University. Primary cultured microglia (over 97\% pure) were prepared, as described previously [32]. Briefly, brain tissues were isolated from newborn Wistar rats, minced, and gently dissociated by trituration in Dulbecco's modified Eagle medium (DMEM). The tissue suspension was filtered through a $50 \mu \mathrm{m}$ diameter nylon mesh into $50 \mathrm{~mL}$ tubes, and cells were collected by centrifugation at $200 \times \mathrm{g}$ for $10 \mathrm{~min}$. Cells were resuspended in DMEM with $10 \%$ fetal calf serum, 100 units/mL penicillin, and $100 \mu \mathrm{g} / \mathrm{mL}$ streptomycin; they were then plated onto $100 \mathrm{~mm}$ diameter dishes at $37^{\circ} \mathrm{C}$ in humidified $5 \% \mathrm{CO}_{2} / 95 \%$ air. We then harvested the floating microglia from mixed glial cultures. Microglia were transferred to 24-well plates $\left(3.0 \times 10^{5}\right.$ cells/well $)$ and were allowed to adhere at $37^{\circ} \mathrm{C}$ overnight; they were then treated with sterilized phosphatebuffered saline (PBS) as the vehicle or synthetic human $A \beta s$ ( $A \beta 40$ or $A \beta 42$; Anaspec, San Jose, $C A$ ) in the presence or absence of calf thymus-purified HMGB1 (WAKO Chemicals,
Osaka, Japan). We previously demonstrated that $1 \mu \mathrm{M} \mathrm{A} \beta 42$ for $12 \mathrm{~h}$ markedly phagocytosed by rat microglia [20], and $0.3 \mu \mathrm{M}$ HMGB1 inhibits the phagocytosis $[32,33]$. When $\mathrm{A} \beta 40$ at $1-3 \mu \mathrm{M}$ were added into the culture, we could detect $\mathrm{A} \beta 40$ phagocytosed by rat microglia by Western blot analysis [25]. Therefore, in the present study, we adopted the concentrations at $1 \mu \mathrm{M}$ and $0.3 \mu \mathrm{M}$ for the treatments with $\mathrm{A} \beta \mathrm{s}$ and HMGB1, respectively. To make the experimental conditions more accurate, we dissolved the lyophilized human $\mathrm{A} \beta$ peptides in distilled and sterilized water at a high concentration, and small aliquots were kept at $-80^{\circ} \mathrm{C}$ until use. Subsequently, $\mathrm{A} \beta$ stock solutions were diluted using sterilized PBS, and once $A \beta$ was thawed, no $A \beta$ was refrozen to eliminate variance due to repeated freezing and thawing.

2.2. Immunocytochemistry. Twelve hours after $\mathrm{A} \beta$ treatment, microglia were gently rinsed three times with PBS and then fixed with $4 \%$ paraformaldehyde in $100 \mathrm{mM}$ phosphate buffer $(\mathrm{PB})$ for $30 \mathrm{~min}$. Cells were then incubated with a mouse monoclonal antibody against $\mathrm{A} \beta$ (clone $6 \mathrm{E} 10$, $1: 1000$; Chemicon, Temecula, CA) and a rabbit polyclonal antibody against HMGB1 $(1: 1000$; BD Pharmingen, San Diego, CA). The primary antibodies were followed by application of a rhodamine-labeled anti-mouse immunoglobulin (Ig)G antibody and fluorescein isothiocyanate-labeled anti-rabbit IgG antibody (each diluted 1:500; Molecular Probes, Eugene, OR). Furthermore, cells were incubated with Hoechst 33258 (1:5000; Molecular Probes) to visualize microglial nuclei. Labeled fluorescence was detected using a laser scanning confocal microscope LSM 510 (Carl Zeiss, Jena, Germany).

2.3. A $\beta$ Phagocytosis and Clearance Assay by Western Blot Analysis. Twelve hours after $\mathrm{A} \beta$ treatment, microglia and culture media were collected and lysed with Laemmli's sample buffer and then analyzed by Western blot analysis. Briefly, samples were subjected to sodium dodecyl sulfatepolyacrylamide gel electrophoresis (SDS-PAGE; 20\% polyacrylamide gels in Tricine buffer). Proteins were transferred to a polyvinylidene difluoride membrane (Millipore, Billerica, MA) by electroelution and then incubated with a mouse monoclonal antibody against $\mathrm{A} \beta$ (clone 6E10, 1:2000; Chemicon), followed by a horseradish peroxidase-linked secondary antibody against mouse IgG $(1: 1,000$; Amersham, Buckinghamshire, UK). Subsequently, protein bands were detected on radiographic films (Kodak, Rochester, NY) using a chemiluminescence kit (ECL kit; Amersham). For semiquantitative analysis, radiographic films were scanned with a CCD color scanner (DuoScan, AGFA, Mortsel, Belgium) and then analyzed densitometrically using the public domain US National Institutes of Health image 1.56 program.

2.4. A $\beta$ Degradation Assay. Microglia were harvested and resuspended in $100 \mathrm{mM}$ Tris- $\mathrm{HCl}$ buffer ( $\mathrm{pH}$ 7.5) containing $10 \mathrm{mM} \mathrm{KCl}, 1.5 \mathrm{mM} \mathrm{MgCl}_{2}$, and $1 \mathrm{mM} \mathrm{DTT}$ and then homogenized. After centrifugation $(50,000 \times \mathrm{g})$ for $20 \mathrm{~min}$ at $4^{\circ} \mathrm{C}$, the protein concentration of the supernatant was measured and used as the microglial cytosolic fraction. 
The $\mathrm{A} \beta$ peptide ( $3 \mu \mathrm{M} \mathrm{A} \beta 40$ or $\mathrm{A} \beta 42)$ was incubated with the microglial cytosolic fraction (final concentration of $1 \mathrm{mg} / \mathrm{mL}$ ) in the presence or absence of $0.3 \mu \mathrm{M}$ HMGB1. At the time points of 0,6 , and $12 \mathrm{~h}$ after incubation, Laemmli's sample buffer was added, and samples were boiled at $100^{\circ} \mathrm{C}$ for $5 \mathrm{~min}$ to stop $\mathrm{A} \beta$ degradation. Subsequently, samples were analyzed using the antibody against $\mathrm{A} \beta$ (clone $6 \mathrm{E} 10$, $1: 2000$; Chemicon) by Western blot analysis, as described previously.

2.5. Immunoprecipitation. HMGB1 $(1.5 \mu \mathrm{g}, 2.6 \mu \mathrm{M})$ was mixed with $3 \mu \mathrm{g}$ of synthetic $\mathrm{A} \beta 40(37.5 \mu \mathrm{M})$ in PBS. Twenty-four hours after incubation, the antibody $(10 \mu \mathrm{g}$ of IgG) against HMGB1 (BD Pharmingen) or $\mathrm{A} \beta$ (clone 6E10; Chemicon) was added to the mixture and further incubated for $2 \mathrm{~h}$ at $4^{\circ} \mathrm{C}$. Protein A-Sepharose $(50 \mu \mathrm{L}$ of a $50 \%$ slurry) was then added, and the mixture was incubated overnight at $4^{\circ} \mathrm{C}$. After centrifugation, immunoprecipitates were resuspended in Laemmli's sample buffer. Subsequently, samples were analyzed using the antibody against HMGB1 $(1: 1000$; BD Pharmingen) or $\mathrm{A} \beta$ (clone 6E10, 1:2000; Chemicon) by Western blot analysis, as described previously.

\subsection{Immunohistochemical Study Using Human AD Brain} Sections. All experiments using human samples were performed in accordance with the guidelines of the ethical committees of Kyoto Pharmaceutical University. Informed consent was obtained from all subjects. For histological examination, frontal cortex tissue from a patient who was clinically and histopathologically diagnosed as human $\mathrm{AD}$ (age, 67 years) was used. Neuropathological assessment of $\mathrm{AD}$ was conducted in accordance with the criteria of the Consortium to Establish a Registry for Alzheimer's Disease (CERAD). Dissected tissue blocks were fixed in 10\% formalin and transferred to a $15 \%$ sucrose solution in $100 \mathrm{mM} \mathrm{PB}$ containing $0.1 \%$ sodium azide at $4^{\circ} \mathrm{C}$. The cryoprotected brain blocks were cut into $20 \mu \mathrm{m}$ sections on a cryostat, and the collected sections were stored in PBS containing $0.3 \%$ Triton X-100 (PBS-T) and $0.1 \%$ sodium azide at $4^{\circ} \mathrm{C}$ until use.

Immunohistochemical study was essentially performed as described previously [34]. Free-floating human brain sections were treated with $0.1 \%$ hydrogen peroxide for $30 \mathrm{~min}$ to quench endogenous peroxidase activity; they were then incubated with $1 \%$ goat serum to block nonspecific binding in PBS. Sections were then incubated with a mouse monoclonal antibody against $\mathrm{A} \beta 40 \quad(1: 1000$; nanoTools, Teningen, Germany) and rabbit polyclonal antibody against A $\beta 42$ (1: 1000; IBL, Gunma, Japan), a rabbit polyclonal antibody against $\mathrm{A} \beta 40(1: 1000$; IBL) and mouse monoclonal antibody against human leukemia antigen (HLA)-DR ( $1: 50$; Dako, Glostrup, Denmark), or a rabbit polyclonal antibody against $\mathrm{A} \beta 42(1: 1000$; IBL $)$ and mouse monoclonal antibody against HLA-DR (1:50; Dako) in PBS-T with $0.1 \%$ sodium azide for 4 days at $4^{\circ} \mathrm{C}$. After washing with PBS-T, the sections were incubated with biotinylated anti-rabbit IgG antibody ( $1: 2000$; Vector Laboratories, Burlingame, CA) for $2 \mathrm{~h}$ at room temperature. The sections were then incubated with avidin peroxidase $(1: 4000$; ABC Elite Kit; Vector Laboratories) for $1 \mathrm{~h}$ at room temperature. Subsequently, labeling was visualized by incubation with $50 \mathrm{mM}$ Tris- $\mathrm{HCl}$ buffer $\left(\mathrm{pH}\right.$ 7.6) containing $0.02 \% 3,3^{\prime}$-diaminobenzidine (DAB) and $0.0045 \%$ hydrogen peroxide with nickel enhancement using $0.6 \%$ nickel ammonium sulfate, which yielded a dark blue color. In the second cycle, sections were incubated with a biotinylated anti-mouse IgG antibody $(1: 2000$; Vector Laboratories) for $2 \mathrm{~h}$ at room temperature. The sections were then incubated with avidin peroxidase $(1: 4000$; ABC Elite Kit; Vector Laboratories) for $1 \mathrm{~h}$ at room temperature. Subsequently, the DAB reaction was performed without nickel ammonium sulfate, which yielded a brown color.

In laser confocal microscopic analysis, human $\mathrm{AD}$ brain sections were treated with $1 \%$ goat serum to block nonspecific binding in PBS. Sections were then coincubated with a rabbit polyclonal antibody against $\mathrm{A} \beta 40(1: 1000 ; \mathrm{IBL})$ and a mouse monoclonal antibody against HLA-DR ( $1: 50$; Dako) or a mouse monoclonal antibody against $\mathrm{A} \beta 40(1: 1000$; nanoTools) and a rabbit polyclonal antibody against HMGB1 ( $1: 1000$; BD Pharmingen) in PBS-T with $0.1 \%$ sodium azide for 4 days at $4^{\circ} \mathrm{C}$. The primary antibodies were probed with Alexa Fluor 546-labeled anti-rabbit IgG antibody and Alexia Fluor 488-labeled anti-mouse IgG antibody or Alexa Fluor 546-labeled anti-mouse IgG antibody and Alexia Fluor 488-labeled anti-rabbit IgG antibody (each diluted 1:500; Molecular Probes). Subsequently, fluorescence was observed using a laser scanning confocal microscope LSM 510 (Carl Zeiss).

2.7. Statistical Evaluation. Results of the densitometric analysis are given as the mean \pm standard error of mean. The statistical significance of differences was determined by analysis of variance. Further statistical analysis for post hoc comparisons was conducted using the Bonferroni/Dunn test (StatView, Abacus Concepts, Berkeley, CA).

\section{Results}

3.1. Binding of $H M G B 1$ with $A \beta 40$. In our previous study, we found that HMGB1 is extracellularly accumulated on $\mathrm{A} \beta$ plaques in $\mathrm{AD}$ brains and further demonstrated that HMGB1 binds to $A \beta 42$ in in vitro cell-free study [33]. In the present cell-free study, we first examined the binding affinity of HMGB1 for A $\beta 40$. Following incubation of the HMGB1 peptide alone, a $29 \mathrm{kDa}$ band of HMGB1 and its high-molecular-weight aggregates was detected, while an approximately $33 \mathrm{kDa}$ band (arrow in Figure 1(a)), which is believed to be a complex of HMGB1 and A $\beta 40$, appeared as an upper band $6 \mathrm{~h}$ after incubation of HMGB1 and $A \beta 40$ peptides (Figure 1(a)). Following incubation with $A \beta 40$ (Figure 1(b)), monomers and oligomers of $A \beta 40$ were the major components present in the absence of HMGB1 at each time point. Predictably, the $33 \mathrm{kDa}$ band, which seemed to be a complex of HMGB1 and A $\beta 40$, was detected by the addition of the HMGB1 peptide (arrow in Figure 1(b)).

To confirm the binding affinity between HMGB1 and $\mathrm{A} \beta 40$, we further examined immunoprecipitation using the 


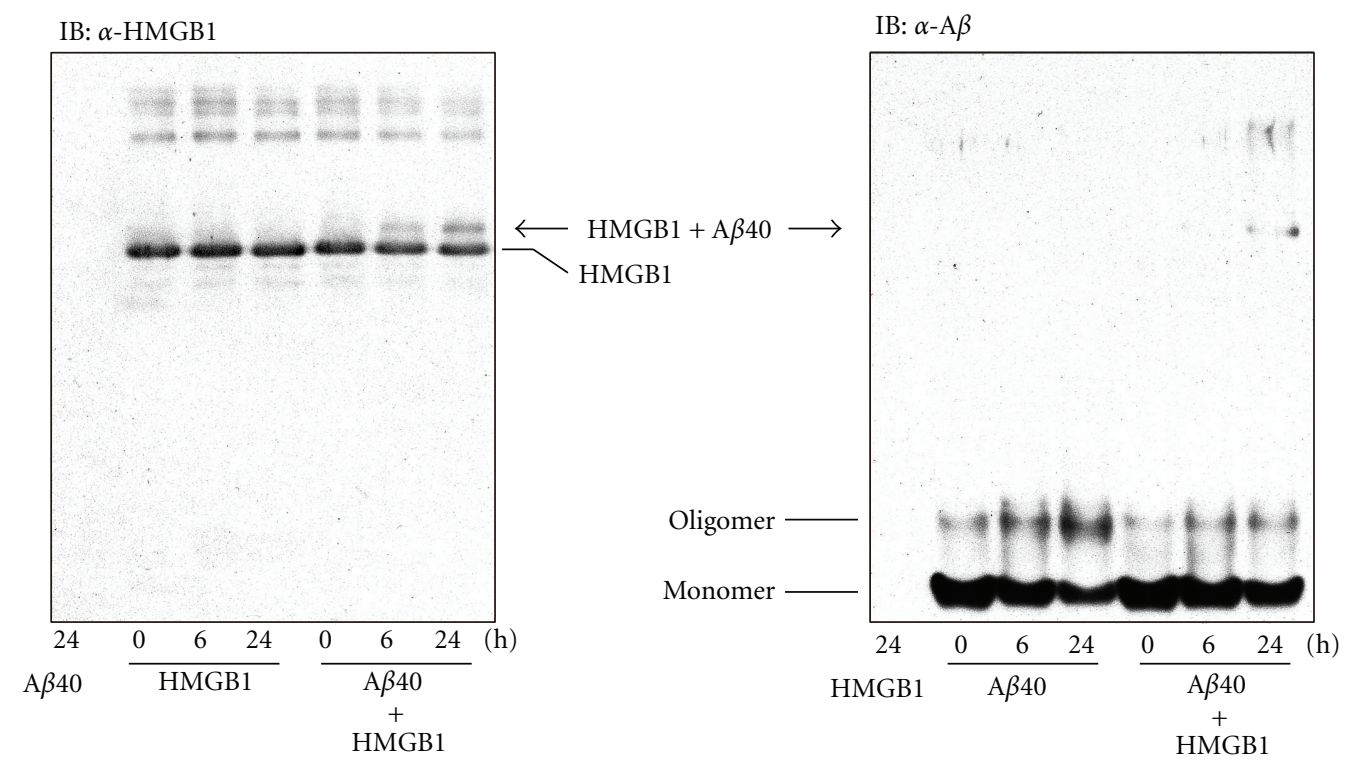

(a)

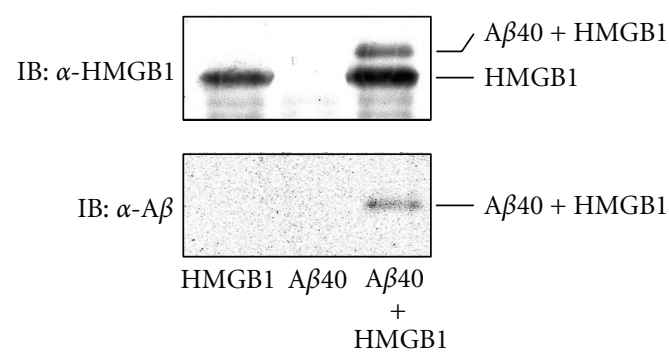

(c) (b)

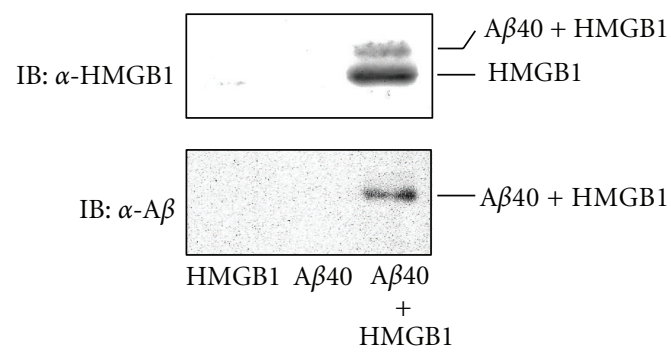

(d)

Figure 1: Binding affinity of HMGB1 for A $\beta 40$. (a, b) After incubation of HMGB1, A $\beta 40$, and the mixture of HMGB1 with A $\beta 40$ for 0,6 , and $24 \mathrm{~h}$, samples were analyzed by Western blot analysis using the anti-HMGB1 antibody (a) or anti-A $\beta$ antibody (b). (c, d) After incubation of HMGB1, A $\beta 40$, and the mixture of HMGB with $A \beta 40$ for $24 \mathrm{~h}$, samples were immunoprecipitated using the anti-HMGB1 antibody (c) or anti-A $\beta$ antibody $(\mathrm{d})$. The precipitates were then analyzed by Western blot analysis using the anti-HMGB1 antibody and anti-A $\beta$ antibody.

anti-HMGB1 antibody (Figure $1(\mathrm{c})$ ) or anti-A $\beta$ antibody (Figure $1(\mathrm{~d})$ ). As a result, in the mixture of HMGB1 and $\mathrm{A} \beta$, the complex of HMGB1 and $\mathrm{A} \beta 40$ (approximately $33 \mathrm{kDa}$ ) was immunoprecipitated with A-Sepharose-linked antibodies against HMGB1 (Figure $1(\mathrm{c})$ ) or A $\beta$ (Figure $1(\mathrm{~d})$ ). These results demonstrated that HMGB1 had a binding affinity for $\mathrm{A} \beta 40$.

3.2. Microglial A $\beta$ Phagocytosis and Effect of Exogenous HMGB1. We previously demonstrated that microglia markedly phagocytose A $\beta 42$ [25], and extracellular HMGB1 inhibits phagocytosis on the cell surface $[32,33]$. In the present study, we analyzed the microglial $A \beta 40$ phagocytosis and the effects of extracellular HMGB1 on phagocytosis using laser confocal microscopy (Figure 2). Endogenous HMGB1 was detected in the nuclei of primary cultured rat microglia (Figures 2(a)-2(f), cyan). When treated with the vehicle (Figure 2(a)) or HMGB1 alone (Figure 2(b)), no
$\mathrm{A} \beta$ immunoreactivity was detected. Consistent with previous studies, in the presence of $A \beta 42$, microglia phagocytosed A $\beta 42$ (Figure 2(c), red), exogenous HMGB1 was colocalized with $\mathrm{A} \beta 42$ on the microglial cell surface, and $\mathrm{A} \beta$ internalization was inhibited (Figure 2(d), yellow). When treated with $\mathrm{A} \beta 40$, the immunoreactivity of $\mathrm{A} \beta 40$ was barely detected in the microglial cytoplasm (Figure 2(e), red). Interestingly, in the presence of exogenous HMGB1, small vesicle-like immunoreactivities of $\mathrm{A} \beta 40$ (Figure 2(f), red) and HMGB1 (Figure 2(f), green) were markedly increased in the microglial cytoplasm, and parts of them were colocalized with each other (Figure 2(f), yellow).

3.3. Amounts of $A \beta 40$ inside and outside Microglia and Effect of Exogenous HMGB1. Twelve hours after A $\beta 40$ treatment, microglial cell lysate and conditioned medium were collected and subjected to Western blot analysis; semiquantitative analysis was then examined to measure the concentration 


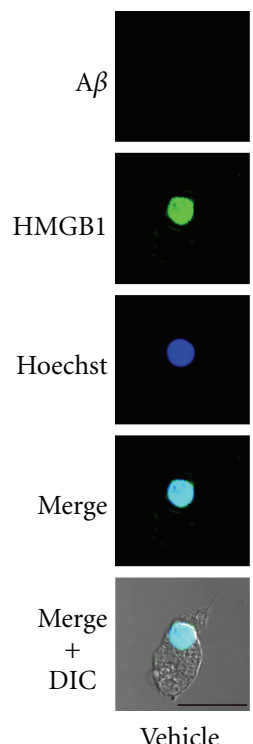

(a)
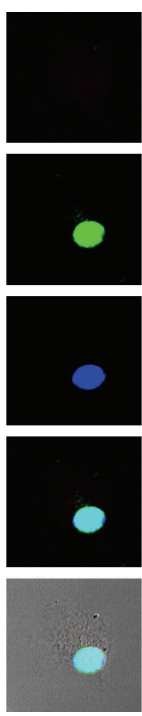

HMGB1

(b)
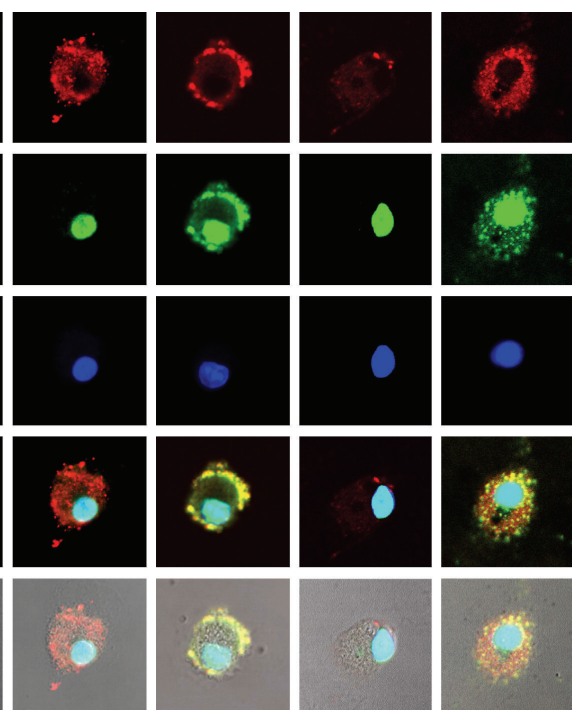

$\mathrm{A} \beta 42$

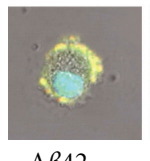

$\mathrm{A} \beta 42$

$\stackrel{+}{+}$

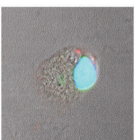

$\mathrm{A} \beta 40$
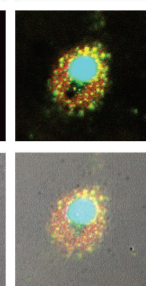

$\mathrm{A} \beta 40$

HMGB1

(d)

(f)

FIGURE 2: Effect of exogenous HMGB1 on microglial A $\beta$ phagocytosis analyzed by laser confocal microscopy. Rat microglia were incubated with the vehicle (a), HMGB1 (b), A $\beta 42$ (c), A $\beta 42$ and HMGB1 (d), A $\beta 40$ (e), or A $\beta 40$ and HMGB1 (f) for 12 h. Fixed cells were further incubated with the anti-A $\beta$ antibody (red), anti-HMGB1 antibody (green), and Hoechst 33258 (dye for nuclei; blue); they were analyzed using a laser scanning confocal microscope. DIC: differential interference contrast. Scale bar $=20 \mu \mathrm{m}$ for all panels.

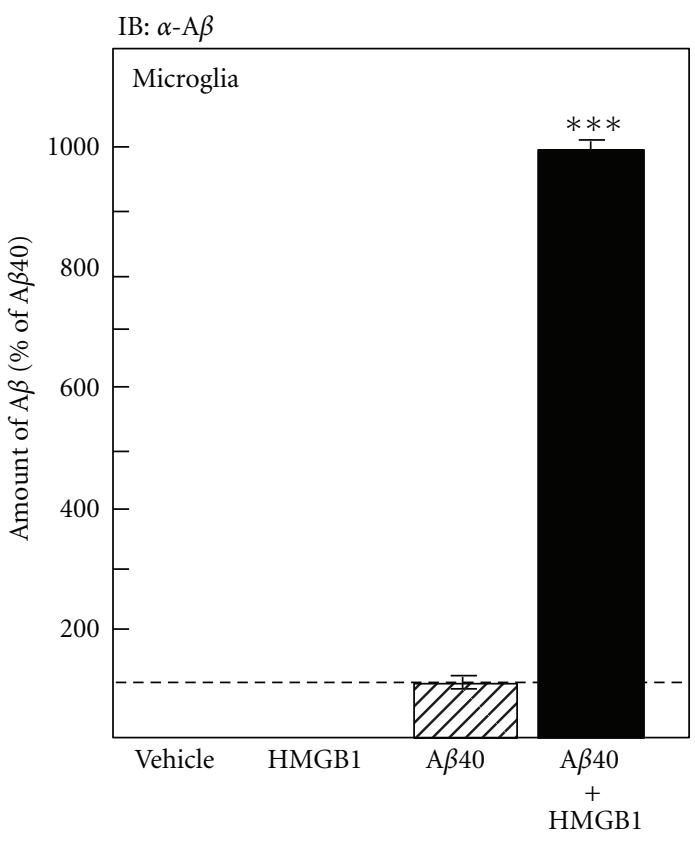

(a)

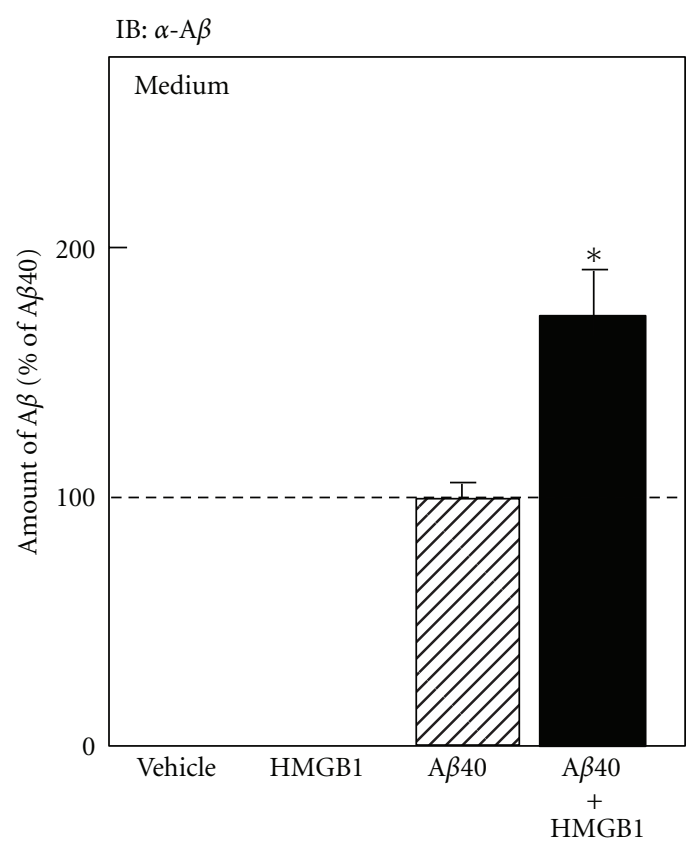

(b)

Figure 3: Effect of exogenous HMGB1 on microglial A $\beta$ phagocytosis analyzed by Western blot. Rat microglia were incubated with the vehicle, HMGB1, A $\beta 40$, or A $\beta 40$ and HMGB1 for $12 \mathrm{~h}$. Microglial cell lysate (a) and conditioned medium (b) were then subjected to Western blot analysis using the anti-A $\beta$ antibody, and then the amounts of $\mathrm{A} \beta 40$ inside (a) and outside microglia (b) were semiquantitatively measured. ${ }^{*} P<0.05,{ }^{* * *} P<0.001$ versus treatment with $\mathrm{A} \beta 40$ alone. 

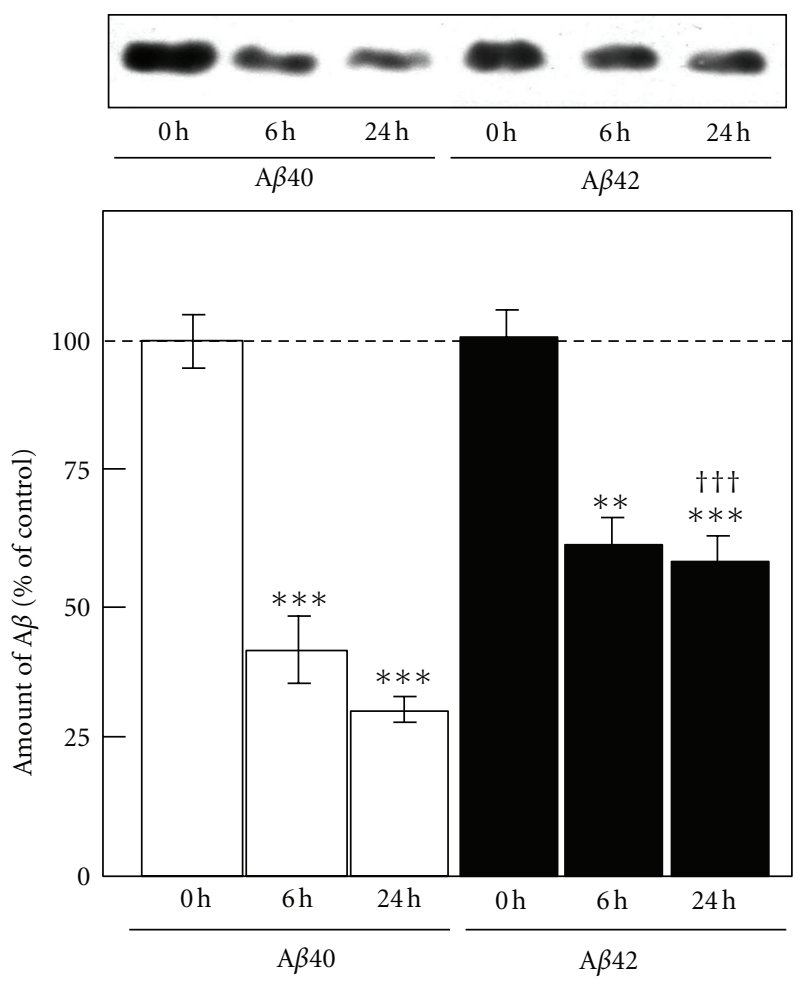

(a)

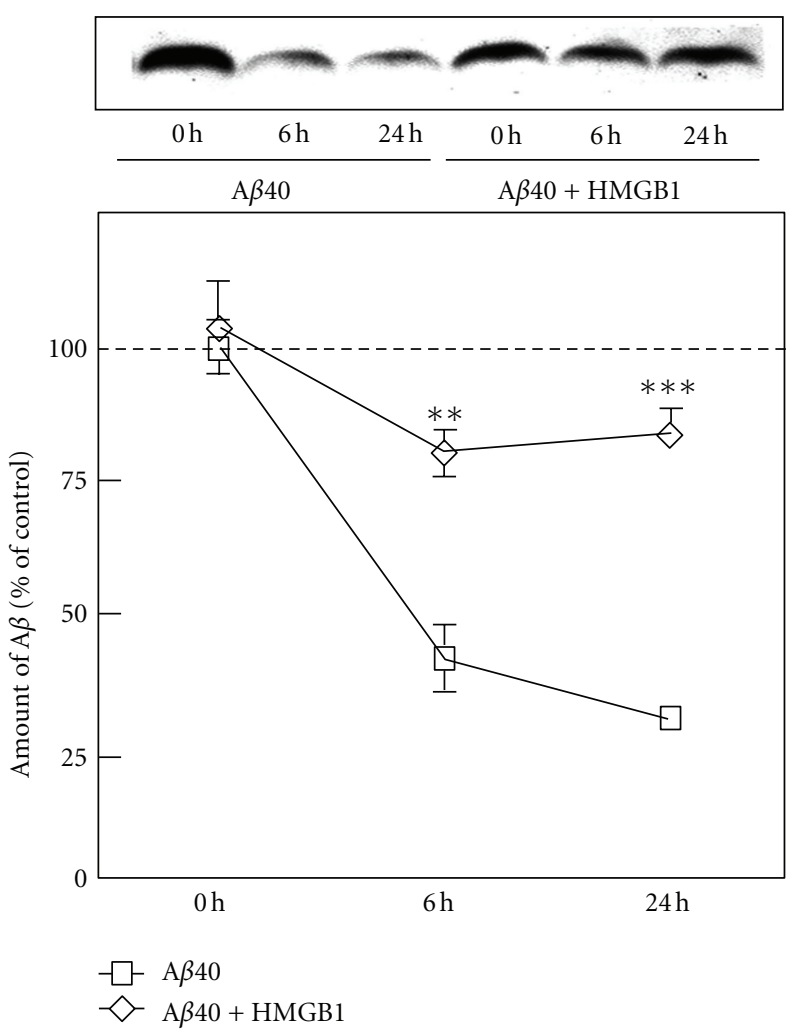

(b)

Figure 4: $\mathrm{A} \beta$ degradation with the microglial cytosolic fraction. (a) $\mathrm{A} \beta 40$ and $\mathrm{A} \beta 42$ were incubated with the rat microglial cytosolic fraction for 0,6 , and $24 \mathrm{~h}$. After incubation, samples were subjected to Western blot analysis using the anti-A $\beta$ antibody, and the amount of $A \beta$ was semiquantitatively measured. ${ }^{* *} P<0.01,{ }^{* * *} P<0.001$ versus time point $0 \mathrm{~h} .{ }^{{ }^{\dagger \dagger}} P<0.001$ versus $\mathrm{A} \beta 40$ at time point $24 \mathrm{~h}$. (b) A $\beta 40$ and A $\beta 40$ with HMGB1 were incubated with rat microglial cytosolic fractions for 0,6 , and $24 \mathrm{~h}$. After incubation, the samples were subjected to Western blot analysis using the anti-A $\beta$ antibody, and the amount of $\mathrm{A} \beta$ was semiquantitatively measured. ${ }^{* *} P<0.01,{ }^{* * *} P<0.001$ versus A $\beta 40$ alone at each time point.

of $\mathrm{A} \beta 40$ inside (Figure 3(a)) and outside microglia (Figure $3(\mathrm{~b}))$. When microglia were treated with the vehicle or exogenous HMGB1 alone, no $\mathrm{A} \beta 40$ immunoreactivity was detected inside them (Figure 3(a)). After treatment with $\mathrm{A} \beta 40$, a small amount of $\mathrm{A} \beta 40$ was detected inside microglia (A $\beta 40$ phagocytosed by microglia), and this amount increased dramatically by simultaneous treatment with exogenous HMGB1 (Figure 3(a)). This result raises two possibilities: (i) extracellular HMGB1 increases microglial A $\beta 40$ uptake, and (ii) HMGB1 inhibits the degradation of $\mathrm{A} \beta 40$ in the microglial cytoplasm after uptake. To address these possibilities, we measured the amount of $\mathrm{A} \beta 40$ in the culture medium (A $\beta 40$ remaining outside microglia) (Figure 3(b)). After treatment with the vehicle or exogenous HMGB1 alone, no $\mathrm{A} \beta$ was detected in the culture medium. Twelve hours after $A \beta 40$ treatment, the amount of $A \beta 40$ in the culture medium significantly increased by simultaneous treatment with exogenous HMGB1. Thus, in the presence of exogenous HMGB1, the amount of $A \beta 40$ both inside and outside microglia was much higher than that when treated with $\mathrm{A} \beta 40$ alone. These results suggest that exogenous HMGB1 phagocytosed by microglia inhibits the degradation of $A \beta 40$ in the microglial cytoplasm and subsequently delays $\mathrm{A} \beta$ clearance by microglia.
3.4. A $\beta$ Degradation with the Microglial Cytosol Fraction and Effect of Exogenous HMGB1. To confirm whether exogenous HMGB1 inhibits $A \beta 40$ degradation in microglial cytoplasm, we prepared cytosolic fractions from rat microglia and mixed them with $\mathrm{A} \beta$. Degradation of $\mathrm{A} \beta 40$ and $\mathrm{A} \beta 42$ by microglial cytosol fractions was compared (Figure $4(\mathrm{a}))$. $\mathrm{A} \beta 40$ and $\mathrm{A} \beta 42$ were gradually degraded by the addition of the microglial cytosolic fraction in a timedependent manner. $\mathrm{A} \beta 40$ was degraded earlier than $\mathrm{A} \beta 42$ (Figure $4(\mathrm{a})$ ). We next examined the effect of exogenous HMGB1 on the $A \beta 40$ degradation induced by the microglial cytosolic fraction (Figure 4(b)). At 6 and $24 \mathrm{~h}$ after incubation, the degradation of $\mathrm{A} \beta 40$ was significantly delayed by the addition of exogenous HMGB1. Thus, this result suggests that exogenous HMGB1 phagocytosed by microglia inhibits the degradation of $A \beta 40$ in the microglial cytoplasm.

3.5. Accumulation of $A \beta 40, A \beta 42$, and Microglia in AD Brains. We further investigated the localization of $A \beta 40$ and $A \beta 42$ in AD brains using specific antibodies (Figures 5(a) and 5(b)) and microglial accumulation on the plaques composed of $\mathrm{A} \beta 40$ (Figures 5(c) and 5(d)) and $\mathrm{A} \beta 42$ (Figures 5(e) and 


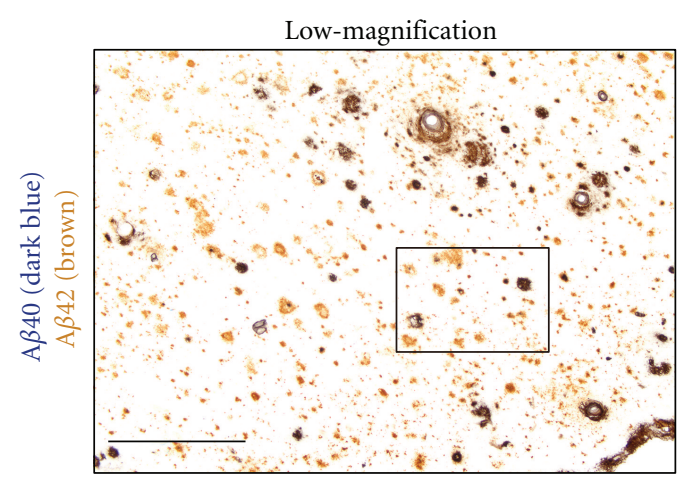

(a)

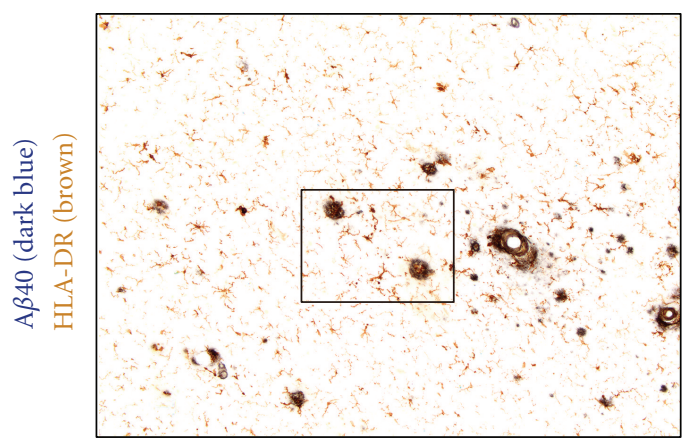

(c)

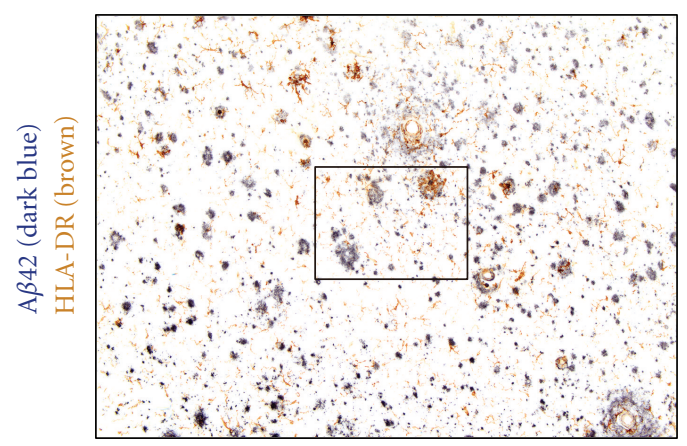

(e)

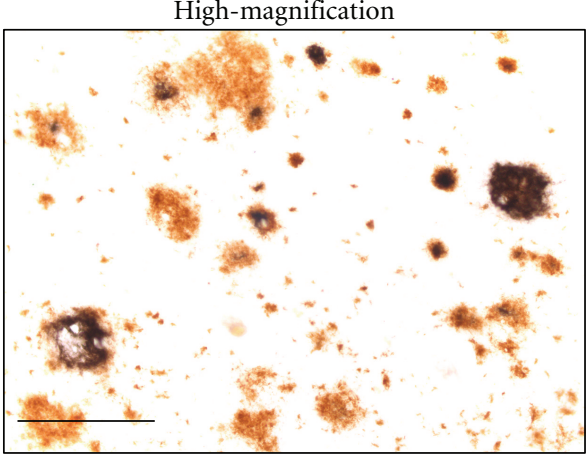

(b)

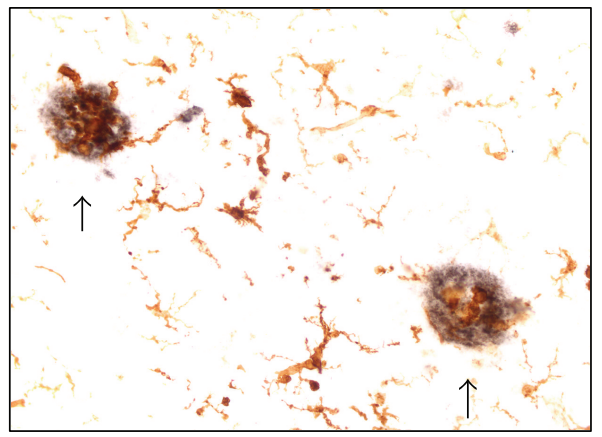

(d)

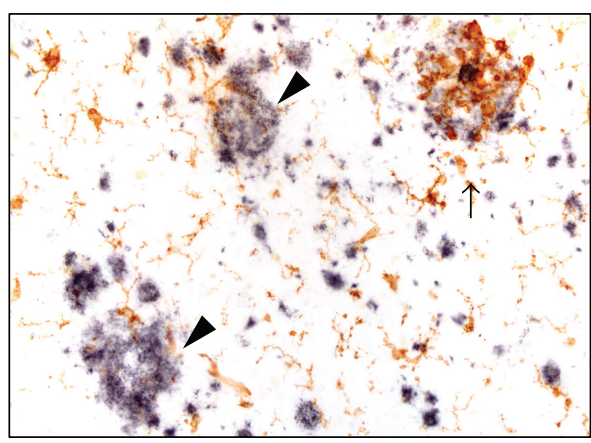

(f)

FIGURE 5: Immunohistochemical study of microglial accumulation on $\mathrm{A} \beta$ plaques in human AD brains. Free-floating human AD brain sections were incubated with the anti-A $\beta 40$ specific antibody (dark blue) and anti-A $\beta 42$ specific antibody (brown) (a, b), anti-A $\beta 40$ specific antibody (dark blue) and anti-HLA-DR antibody (for microglial staining; brown) (c, d), and anti-A $\beta 42$ specific antibody (dark blue) and anti-HLA-DR antibody (for microglial staining; brown). Arrows and arrow heads show marked and poor microglial accumulations, respectively. (b), (d), and (f) show high-magnification views of squared area in (a), (c), and (e), respectively. Scale bar in (a) equals $400 \mu \mathrm{m}$ for (a), (c), and (e). Scale bar in (b) equals $100 \mu \mathrm{m}$ for (b), (d), and (f).

5(f)). The number of $A \beta 40$ plaques (dark blue deposits in Figure 5(a)) was lesser than that of $\mathrm{A} \beta 42$ plaques (brown deposits in Figure 5(a)). High-magnification photographs revealed that $A \beta 40$ accumulated on $A \beta 42$ plaques (Figure 5(b)). Regarding microglial accumulations (Figures 5(c)$5(\mathrm{f})$ ), almost all $\mathrm{A} \beta 40$ plaques were markedly surrounded by activated microglia (Figure 5(c) and arrows in Figure 5(d)). Although some $A \beta 42$ plaques were markedly accumulated by microglia (Figure 5(e) and arrow in Figure 5(f)), others were moderately or poorly surrounded by microglia (arrowheads in Figure 5(f)).
3.6. Accumulation of HMGB1 and Microglia on A $\beta 40$ Plaques in $A D$ Brains. We previously demonstrated that extracellular HMGB1 accumulates on $A \beta$ plaques, as detected using an anti-A $\beta$ antibody that reacts with a broad spectrum of $A \beta$ species [33]. Therefore, in the present study, we investigated the colocalization of extracellular HMGB1 on $\mathrm{A} \beta 40$ plaques in $\mathrm{AD}$ brains using a specific anti-A $\beta 40$ antibody. Consistent with the immunohistochemical study (Figures 5(c) and 5(d)), microglia (Figure 6(b)) markedly accumulated on $\mathrm{A} \beta 40$ plaques (Figure $6(\mathrm{a})$ ) in $\mathrm{AD}$ brains (Figure 6(c)). We further demonstrated that extracellular HMGB1 


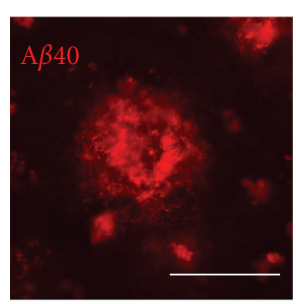

(a)

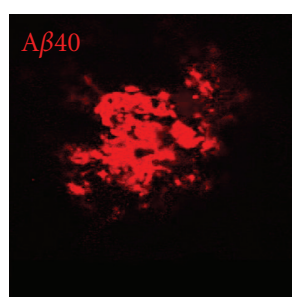

(d)

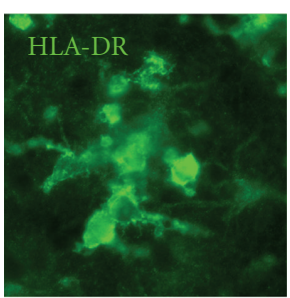

(b)

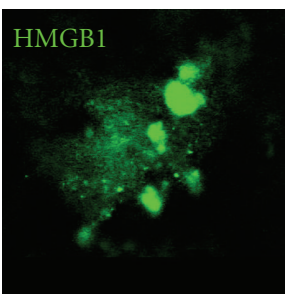

(e)

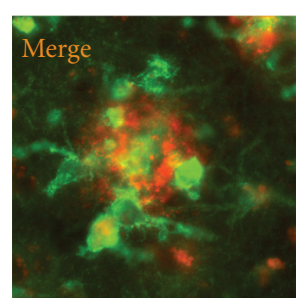

(c)

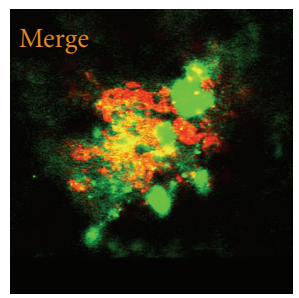

(f)

FIGURE 6: Laser confocal microscopic study on the accumulation of HMGB1 and microglia on A $\beta 40$ plaques in human AD brains. (a-c) Free-floating human $\mathrm{AD}$ brain sections were incubated with the anti-A $\beta 40$ specific antibody ((a) red) and anti-HLA-DR antibody ((b) for microglial staining, green). The merged image is indicated in (c). (d-f) Free-floating human AD brain sections were incubated with the anti-A $\beta 40$ specific antibody ((a); red) and anti-HMGB1 antibody ((b); green). The merged image is indicated in (f). Scale bar in (a) equals $50 \mu \mathrm{m}$ for all panels.

(Figure 6(e)) colocalized with A $\beta 40$ plaques (Figure 6(d)) in AD brains (Figure 6(f)).

\section{Discussion}

In studies on familial $\mathrm{AD}$, mutations in the $A P P, P S 1$, and PS2 genes have been detected, and transgenic mice models carrying these familial AD-linked mutations show enhanced $\mathrm{A} \beta$ production in their brains. In particular, transgenic mice carrying the APP mutation display characteristics that closely resemble $\mathrm{AD}$, such as $\mathrm{A} \beta$ deposition and memory dysfunction $[35,36]$, and introduction of the double mutations of PS/APP exhibits the early onset of these pathologies [37]. Thus, all mutations are involved in $\mathrm{A} \beta$ generation, and the accumulation of $A \beta$ in the brain has been strongly suggested to be the primary event driving the pathogenesis of $\mathrm{AD}$. However, familial $\mathrm{AD}$ accounts for less than $1 \%$ of all $\mathrm{AD}$ cases [38]; most cases develop sporadically. Although the etiology of sporadic $\mathrm{AD}$ remains much more elusive than that of familial cases, neurological and pathological events in sporadic $\mathrm{AD}$ are essentially indistinguishable from those in familial cases. In sporadic $\mathrm{AD}$, a decreased $\mathrm{A} \beta$ clearance rate has been reported [39].

One proposed mechanism of $A \beta$ clearance is microglial $\mathrm{A} \beta$ phagocytosis $[40,41]$. Reports on $\mathrm{AD}$ patients treated with $\mathrm{A} \beta$ immunization also indicate microglial contribution to $\mathrm{A} \beta$ clearance in human $\mathrm{AD}$ brains $[42,43]$. However, it has been suggested that the ability of microglia to clear $A \beta$ decreases with age and progression of AD pathology [26, 27], and it may, at least in part, account for the dysregulation of $\mathrm{A} \beta$ clearance in sporadic $\mathrm{AD}$.

HMGB1 inhibits microglial A $\beta 42$ phagocytosis by interfering with $A \beta 42$ internalization $[32,33]$. In the present study, we further showed that exogenous HMGB1 inhibits the degradation of $\mathrm{A} \beta 40$ in rat microglial cytoplasm and subsequently delays $A \beta 40$ clearance. We demonstrated the binding affinities of HMGB1 for $\mathrm{A} \beta 40$ and $\mathrm{A} \beta 42$ [33]. $\mathrm{A} \beta$ contains an amino acid sequence $\left({ }^{18} \mathrm{VFFA}^{21}\right)$ that has been identified to be essential for aggregation and fibril formation [44]. Interestingly, HMGB1 contains a homologous motif $\left({ }^{16} \mathrm{AFFV}^{19}\right)$, and this sequence is thought to be critically involved in the interactions of A $\beta$ with HMGB1 $[33,45]$. Among the many peptidases that have been proposed as $A \beta$ degrading enzymes [46], insulin-degrading enzyme, cathep$\sin \mathrm{D}$, and neprilysin are the principle enzymes involved in microglia-mediated $\mathrm{A} \beta$ degradation [25, 47, 48]. Many cleavage sites that are the targets of microglial $\mathrm{A} \beta$-degrading enzymes are located on and in the vicinity of the amino acid sequence $\left({ }^{18} \mathrm{VFFA}^{21}\right)$ of $A \beta[46]$. Therefore, we speculate that the cleavage sites of $A \beta$ are masked by the binding of HMGB1; subsequently, the degradation of $A \beta 40$ may be inhibited in the microglial cytoplasm. In case of $A \beta 42, A \beta 42$ itself forms high-molecular-weight fibrils during incubation [33]. Therefore, the binding of HMGB1 may stabilize A $\beta 42$ fibril formation, and high-molecular-weight complex of HMGB1 and $A \beta 42$ fibril may interrupt the uptake of $A \beta 42$ by microglia. Thus, extracellular HMGB1 may serve as a chaperone protein for $A \beta$ and inhibit microglial $A \beta$ clearance by interrupting $A \beta 40$ degradation and $A \beta 42$ internalization by microglia. On the other hand, RAGE, TLR2, and TLR4 are receptors for HMGB1 [30, 31]; they are also involved in microglial $\mathrm{A} \beta$ phagocytosis $[49,50]$. Therefore, there is a possibility that the interactions of HMGB1 with these receptors on microglia may be related to the inhibitory events on $\mathrm{A} \beta$.

Consistent with a previous study [13], plaques containing $\mathrm{A} \beta 42$ predominantly existed in $\mathrm{AD}$ brains, and 
$\mathrm{A} \beta 40$ accumulated on parts of $\mathrm{A} \beta 42$ plaques. Despite the restricted distribution of $A \beta 40$, almost all plaques containing $\mathrm{A} \beta 40$ were markedly surrounded by activated microglia. We previously reported that small oligomers formed by $\mathrm{A} \beta 40$ strongly induce rat microglial reactions such as cytokine production [51]. Thus, A $\beta 40$ may play an important role in microglial activation and/or recruitment on $A \beta$ plaques. However, we have found that the level of HMGB1 was significantly increased in AD brains [33], and extracellular HMGB1 accumulated on $A \beta$ plaques. Therefore, in $A D$ brains, microglial degradation of $\mathrm{A} \beta 40$ and uptake of $\mathrm{A} \beta 42$ may be inhibited by extracellular HMGB1 despite the marked accumulation of reactive microglia on $A \beta$ plaques. Moreover, in the present study, we demonstrated that A $\beta 40$ is more readily degraded by the microglial cytosolic fraction than $A \beta 42$. However, in the presence of exogenous HMGB1, the degradation of $\mathrm{A} \beta 40$ by microglia is inhibited, and a lot of $\mathrm{A} \beta 40$ granules are existed in the cytoplasm of rat microglia as shown in Figure 2(f). Interestingly, numerous microglia containing $\mathrm{A} \beta 40$ granules, but not $\mathrm{A} \beta 42$, have also been detected in AD brains [52]. Thus, this event in AD brain is well replicated by the treatment with $A \beta 40$ in the presence of extracellular HMGB1 in primary-cultured rat microglia. Results suggest that our findings in the effect of HMGB1 on rat microglia may reflect on the pathological event induced in $\mathrm{AD}$ brain and are expected the critical implication of extracellular HMGB1 in the progression of $\mathrm{AD}$ pathologies. In addition, we have postulated that the origin of extracellular HMGB1 is leakage from dead neurons during the progression of $\mathrm{AD}$ [32], like ischemic neurodegeneration [53]. Extracellular HMGB1 leaked from dead neurons may then accumulate on $\mathrm{A} \beta$ plaques through its binding affinity for $\mathrm{A} \beta$ in $\mathrm{AD}$ brains.

It has been reported that the released HMGB1 is involved in the pathologies of various inflammatory-related disease [54]. In ischemic stroke [55] and intracerebral hemorrhage especially [56], extracellular HMGB1 is suggested to exacerbate brain insult through the disruption of the blood-brain barrier (BBB), overfacilitation of microglia, and intense production of proinflammatory molecules. These studies also demonstrated that a neutralizing anti-HMGB1 monoclonal antibody and glycyrrhizin which bind to and inhibit cytokine-like activity of HMGB1 attenuate the brain insult induced by transient ischemia and intracerebral hemorrhage in rat, respectively. Therefore, there is a possibility that the neutralizing anti-HMGB1 monoclonal antibody and glycyrrhizin may bind to the extracellular HMGB1 accumulated on the $\mathrm{A} \beta$ plaques in the $\mathrm{AD}$ brain, cancel the inhibitory effects of HMGB1 on microglial $A \beta$ phagocytosis, and then may provide novel therapeutic options for the $\mathrm{AD}$ treatment.

In conclusion, in the present study, we found that HMGB1 extracellularly accumulates on $\mathrm{A} \beta$ plaques containing $\mathrm{A} \beta 40$ in $\mathrm{AD}$ brains. We further demonstrated that HMGB1 has a binding affinity for $A \beta 40$, and exogenous HMGB1 is internalized into rat microglial cytoplasm with $\mathrm{A} \beta 40$ and inhibits $\mathrm{A} \beta 40$ degradation. Subsequently, exogenous HMGB1 delays $A \beta 40$ clearance in the culture medium. Thus, these results suggest that extracellular
HMGB1 attenuates microglial $A \beta$ clearance and is possibly involved in the progression of AD pathology.

\section{Acknowledgments}

The authors thank Toshiyuki Kawasaki for his technical assistance. This study was supported by the Frontier Research Programs of the Ministry of Education, Culture, Sports, Science and Technology of Japan; Grants-in-Aid from the Japan Society for the Promotion of Science; and Kyoto Pharmaceutical University Fund for the Promotion of Scientific Research.

\section{References}

[1] D. J. Selkoe, “Alzheimer's disease is a synaptic failure," Science, vol. 298, no. 5594, pp. 789-791, 2002.

[2] J. Götz, F. Chen, J. Van Dorpe, and R. M. Nitsch, "Formation of neurofibrillary tangles in P301L tau transgenic mice induced by Aß42 fibrils," Science, vol. 293, no. 5534, pp. 1491-1495, 2001.

[3] J. Lewis, D. W. Dickson, W. L. Lin et al., "Enhanced neurofibrillary degeneration in transgenic mice expressing mutant tau and APP," Science, vol. 293, no. 5534, pp. 1487-1491, 2001.

[4] K. Takata, Y. Kitamura, Y. Nakata et al., "Involvement of WAVE accumulation in A $\beta /$ APP pathology-dependent tangle modification in Alzheimer's disease," American Journal of Pathology, vol. 175, no. 1, pp. 17-24, 2009.

[5] F. Bard, C. Cannon, R. Barbour et al., "Peripherally administered antibodies against amyloid $\beta$-peptide enter the central nervous system and reduce pathology in a mouse model of Alzheimer disease," Nature Medicine, vol. 6, no. 8, pp. 916919, 2000.

[6] J. C. Dodart, K. R. Bales, K. S. Gannon et al., "Immunization reverses memory deficits without reducing brain $\mathrm{A} \beta$ burden in Alzheimer's disease model," Nature Neuroscience, vol. 5, no. 5, pp. 452-457, 2002.

[7] C. Janus, J. Pearson, J. McLaurin et al., "A $\beta$ peptide immunization reduces behavioural impairment and plaques in a model of Alzheimer's disease," Nature, vol. 408, no. 6815, pp. 979$982,2000$.

[8] D. Morgan, D. M. Diamond, P. E. Gottschall et al., "A $\beta$ peptide vaccination prevents memory loss in an animal model of Alzheimer's disease," Nature, vol. 408, no. 6815, pp. 982985, 2000.

[9] D. Schenk, R. Barbour, W. Dunn et al., "Immunization with amyloid- $\beta$ attenuates Alzheimer disease-like pathology in the PDAPP mouse," Nature, vol. 400, no. 6740, pp. 173-177, 1999.

[10] C. Hock, U. Konietzko, J. R. Streffer et al., "Antibodies against $\beta$-amyloid slow cognitive decline in Alzheimer's disease," Neuron, vol. 38, no. 4, pp. 547-554, 2003.

[11] J. Hardy and D. J. Selkoe, "The amyloid hypothesis of Alzheimer's disease: progress and problems on the road to therapeutics," Science, vol. 297, no. 5580, pp. 353-356, 2002.

[12] J. Wiltfang, H. Esselmann, M. Bibl et al., "Highly conserved and disease-specific patterns of carboxyterminally truncated A $\beta$ peptides $1-37 / 38 / 39$ in addition to $1-40 / 42$ in Alzheimer's disease and in patients with chronic neuroinflammation," Journal of Neurochemistry, vol. 81, no. 3, pp. 481-496, 2002.

[13] T. Iwatsubo, A. Odaka, N. Suzuki, H. Mizusawa, N. Nukina, and Y. Ihara, "Visualization of $\mathrm{A} \beta 42(43)$ and $\mathrm{A} \beta 40$ in senile plaques with end-specific $\mathrm{A} \beta$ monoclonals: evidence that an 
initially deposited species is A $\beta 42(43)$," Neuron, vol. 13, no. 1, pp. 45-53, 1994.

[14] J. T. Jarrett, E. P. Berger, and P. T. Lansbury Jr., "The carboxy terminus of the $\beta$ amyloid protein is critical for the seeding of amyloid formation: implications for the pathogenesis of Alzheimer's disease," Biochemistry, vol. 32, no. 18, pp. 46934697, 1993.

[15] K. N. Dahlgren, A. M. Manelli, W. Blaine Stine, L. K. Baker, G. A. Krafft, and M. J. Ladu, "Oligomeric and fibrillar species of amyloid- $\beta$ peptides differentially affect neuronal viability," Journal of Biological Chemistry, vol. 277, no. 35, pp. 3204632053, 2002.

[16] L. F. Lue, Y. M. Kuo, A. E. Roher et al., "Soluble amyloid $\beta$ peptide concentration as a predictor of synaptic change in Alzheimer's disease," American Journal of Pathology, vol. 155, no. 3, pp. 853-862, 1999.

[17] L. S. Perlmutter, E. Barron, and H. C. Chui, "Morphologic association between microGlia and senile plaque amyloid in Alzheimer's disease," Neuroscience Letters, vol. 119, no. 1, pp. 32-36, 1990.

[18] D. M. Paresce, R. N. Ghosh, and F. R. Maxfield, "MicroGlial cells internalize aggregates of the Alzheimer's disease amyloid $\beta$-protein via a scavenger receptor," Neuron, vol. 17, no. 3, pp. 553-565, 1996.

[19] D. M. Paresce, H. Chung, and F. R. Maxfield, "Slow degradation of aggregates of the Alzheimer's disease amyloid $\beta$ protein by microGlial cells," Journal of Biological Chemistry, vol. 272, no. 46, pp. 29390-29397, 1997.

[20] K. Takata, Y. Kitamura, M. Saeki et al., "Galantamine-induced amyloid- $\beta$ clearance mediated via stimulation of microGlial nicotinic acetylcholine receptors," Journal of Biological Chemistry, vol. 285, no. 51, pp. 40180-40191, 2010.

[21] K. Takata, C. Hirata-Fukae, A. G. Becker et al., "Deglycosylated anti-amyloid beta antibodies reduce microGlial phagocytosis and cytokine production while retaining the capacity to induce amyloid beta sequestration," European Journal of Neuroscience, vol. 26, no. 9, pp. 2458-2468, 2007.

[22] K. Takata, Y. Kitamura, D. Yanagisawa et al., "MicroGlial transplantation increases amyloid- $\beta$ clearance in Alzheimer model rats," FEBS Letters, vol. 581, no. 3, pp. 475-478, 2007.

[23] Y. Kitamura, K. Shibagaki, K. Takata et al., "Involvement of Wiskott-Aldrich syndrome protein family verprolinhomologous protein (WAVE) and Racl in the phagocytosis of amyloid- $\beta$ (1-42) in rat microGlia," Journal of Pharmacological Sciences, vol. 92, no. 2, pp. 115-123, 2003.

[24] K. Takata, Y. Kitamura, D. Tsuchiya, T. Kawasaki, T. Taniguchi, and S. Shimohama, "Heat shock protein-90induced microGlial clearance of exogenous amyloid- $\beta 1-42$ in rat hippocampus in vivo," Neuroscience Letters, vol. 344, no. 2 , pp. 87-90, 2003.

[25] J. I. Kakimura, Y. Kitamura, K. Takata et al., "MicroGlial activation and amyloid- $\beta$ clearance induced by exogenous heat-shock proteins," FASEB Journal, vol. 16, no. 6, pp. 601603, 2002.

[26] W. J. Streit, N. W. Sammons, A. J. Kuhns, and D. L. Sparks, "Dystrophic MicroGlia in the Aging Human Brain," Glia, vol. 45, no. 2, pp. 208-212, 2004.

[27] S. E. Hickman, E. K. Allison, and J. El Khoury, "MicroGlial dysfunction and defective $\beta$-amyloid clearance pathways in aging alzheimer's disease mice," Journal of Neuroscience, vol. 28, no. 33, pp. 8354-8360, 2008.
[28] S. Müller, P. Scaffidi, B. Degryse et al., "The double life of HMGB1 chromatin protein: architectural factor and extracellular signal," EMBO Journal, vol. 20, no. 16, pp. 4337-4340, 2001.

[29] P. Scaffidi, T. Misteli, and M. E. Bianchi, "Release of chromatin protein HMGB1 by necrotic cells triggers inflammation," Nature, vol. 418, no. 6894, pp. 191-195, 2002.

[30] J. S. Park, D. Svetkauskaite, Q. He et al., "Involvement of tolllike receptors 2 and 4 in cellular activation by high mobility group box 1 protein," Journal of Biological Chemistry, vol. 279, no. 9, pp. 7370-7377, 2004.

[31] R. Kokkola, A. Andersson, G. Mullins et al., "RAGE is the major receptor for the proinflammatory activity of HMGB1 in rodent macrophages," Scandinavian Journal of Immunology, vol. 61, no. 1, pp. 1-9, 2005.

[32] K. Takata, Y. Kitamura, D. Tsuchiya, T. Kawasaki, T. Taniguchi, and S. Shimohama, "High mobility group box protein-1 inhibits microGlial $\mathrm{A} \beta$ clearance and enhances $\mathrm{A} \beta$ neurotoxicity," Journal of Neuroscience Research, vol. 78, no. 6, pp. 880891, 2004.

[33] K. Takata, Y. Kitamura, J. I. Kakimura et al., "Role of high mobility group protein-1 (HMG1) in amyloid- $\beta$ homeostasis," Biochemical and Biophysical Research Communications, vol. 301, no. 3, pp. 699-703, 2003.

[34] Y. Kitamura, S. Shimohama, W. Kamoshima et al., "Alteration of proteins regulating apoptosis, $\mathrm{Bcl}-2, \mathrm{Bcl}-\mathrm{x}, \mathrm{Bax}, \mathrm{Bak}, \mathrm{Bad}$, ICH-1 and CPP32, in Alzheimer's disease," Brain Research, vol. 780, no. 2, pp. 260-269, 1998.

[35] D. Games, D. Adams, R. Alessandrini et al., "Alzheimer-type neuropathology in transgenic mice overexpressing V717F $\beta$ amyloid precursor protein," Nature, vol. 373, no. 6514, pp. 523-527, 1995.

[36] K. Hsiao, P. Chapman, S. Nilsen et al., "Correlative memory deficits, $\mathrm{A} \beta$ elevation, and amyloid plaques in transgenic mice," Science, vol. 274, no. 5284, pp. 99-102, 1996.

[37] L. Holcomb, M. N. Gordon, E. Mcgowan et al., "Accelerated Alzheimer-type phenotype in transgenic mice carrying both mutant amyloid precursor protein and presenilin 1 transgenes," Nature Medicine, vol. 4, no. 1, pp. 97-100, 1998.

[38] D. Campion, C. Dumanchin, D. Hannequin et al., "Earlyonset autosomal dominant Alzheimer disease: prevalence, genetic heterogeneity, and mutation spectrum," American Journal of Human Genetics, vol. 65, no. 3, pp. 664-670, 1999.

[39] K. G. Mawuenyega, W. Sigurdson, V. Ovod et al., "Decreased clearance of CNS $\beta$-amyloid in Alzheimer's disease," Science, vol. 330, no. 6012, p. 1774, 2010.

[40] A. R. Simard, D. Soulet, G. Gowing, J. P. Julien, and S. Rivest, "Bone marrow-derived microGlia play a critical role in restricting senile plaque formation in Alzheimer's disease," Neuron, vol. 49, no. 4, pp. 489-502, 2006.

[41] J. El Khoury, M. Toft, S. E. Hickman et al., "Ccr2 deficiency impairs microGlial accumulation and accelerates progression of Alzheimer-like disease," Nature Medicine, vol. 13, no. 4, pp. 432-438, 2007.

[42] D. Boche, N. Denham, C. Holmes, and J. A. R. Nicoll, "Neuropathology after active $A \beta 42$ immunotherapy: implications for Alzheimer's disease pathogenesis," Acta Neuropathologica, vol. 120, no. 3, pp. 369-384, 2010.

[43] J. A. R. Nicolll, D. Wilkinson, C. Holmes, P. Steart, H. Markham, and R. O. Weller, "Neuropathology of human Alzheimer disease after immunization with amyloid- $\beta$ peptide: a case report," Nature Medicine, vol. 9, no. 4, pp. 448-452, 2003. 
[44] L. O. Tjernberg, D. J. E. Callaway, A. Tjernberg et al., "A molecular model of Alzheimer amyloid $\beta$-peptide fibril formation," Journal of Biological Chemistry, vol. 274, no. 18, pp. 12619-12625, 1999.

[45] J. Kallijärvi, M. Haltia, and M. H. Baumann, "Amphoterin includes a sequence motif which is homologous to the Alzheimer's $\beta$-amyloid peptide $(\mathrm{A} \beta)$, forms amyloid fibrils in vitro, and binds avidly to A $\beta$," Biochemistry, vol. 40, no. 34, pp. 10032-10037, 2001.

[46] N. Iwata, M. Higuchi, and T. C. Saido, "Metabolism of amyloid- $\beta$ peptide and Alzheimer's disease," Pharmacology and Therapeutics, vol. 108, no. 2, pp. 129-148, 2005.

[47] W. Q. Qiu, D. M. Walsh, Z. Ye et al., "Insulin-degrading enzyme regulates extracellular levels of amyloid $\beta$ - protein by degradation," Journal of Biological Chemistry, vol. 273, no. 49, pp. 32730-32738, 1998.

[48] E. Shimizu, K. Kawahara, M. Kajizono, M. Sawada, and H. Nakayama, "IL-4-induced selective clearance of oligomeric $\beta$-amyloid peptide $1-42$ by rat primary type 2 microGlia," Journal of Immunology, vol. 181, no. 9, pp. 6503-6513, 2008.

[49] L. F. Lue, D. G. Walker, L. Brachova et al., "Involvement of microGlial receptor for advanced glycation endproducts (RAGE)in Alzheimer's disease: identification of a cellular activation mechanism," Experimental Neurology, vol. 171, no. 1, pp. 29-45, 2001.

[50] K. Tahara, H. D. Kim, J. J. Jin, J. A. Maxwell, L. Li, and K. I. Fukuchi, "Role of toll-like receptor signalling in $\mathrm{A} \beta$ uptake and clearance," Brain, vol. 129, no. 11, pp. 3006-3019, 2006.

[51] K. Takata, Y. Kitamura, M. Umeki et al., "Possible involvement of small oligomers of amyloid- $\beta$ peptides in 15-deoxy$\Delta 12,14$ prostaglandin J2-sensitive microGlial activation," Journal Pharmacological Sciences, vol. 91, no. 4, pp. 330-333, 2003.

[52] H. Akiyama, H. Mori, T. Saido, H. Kondo, K. Ikeda, and P. L. McGeer, "Occurrence of the diffuse amyloid $\beta$-protein $(\mathrm{A} \beta)$ deposits with numerous $\mathrm{A} \beta$-containing Glial cells in the cerebral cortex of patients with Alzheimer's disease," Glia, vol. 25, no. 4, pp. 324-331, 1999.

[53] G. Faraco, S. Fossati, M. E. Bianchi et al., "High mobility group box 1 protein is released by neural cells upon different stresses and worsens ischemic neurodegeneration in vitro and in vivo," Journal of Neurochemistry, vol. 103, no. 2, pp. 590-603, 2007.

[54] M. T. Lotze and K. J. Tracey, "High-mobility group box 1 protein (HMGB1): nuclear weapon in the immune arsenal," Nature Reviews Immunology, vol. 5, no. 4, pp. 331-342, 2005.

[55] K. Liu, S. Mori, H. K. Takahashi et al., "Anti-high mobility group box 1 monoclonal antibody ameliorates brain infarction induced by transient ischemia in rats," FASEB Journal, vol. 21, no. 14, pp. 3904-3916, 2007.

[56] M. Ohnishi, H. Katsuki, C. Fukutomi et al., "HMGB1 inhibitor glycyrrhizin attenuates intracerebral hemorrhageinduced injury in rats," Neuropharmacology, vol. 61, no. 5-6, pp. 975-980, 2011. 


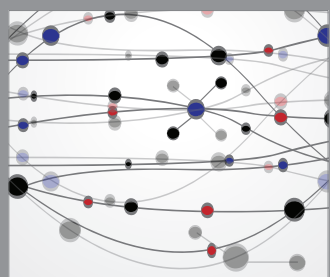

The Scientific World Journal
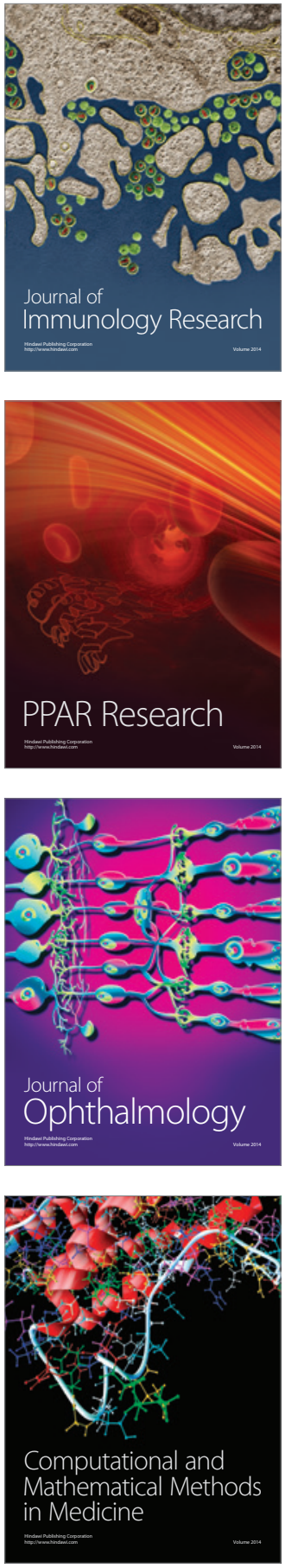

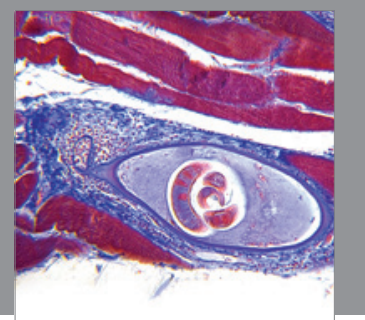

Gastroenterology

Research and Practice
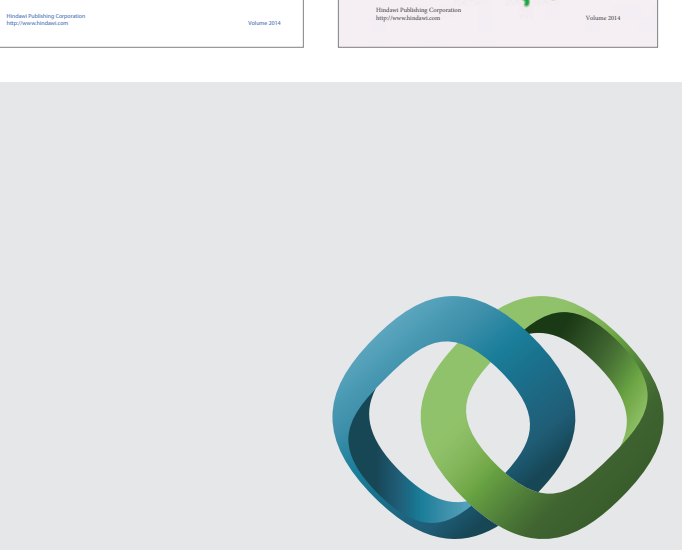

\section{Hindawi}

Submit your manuscripts at

http://www.hindawi.com
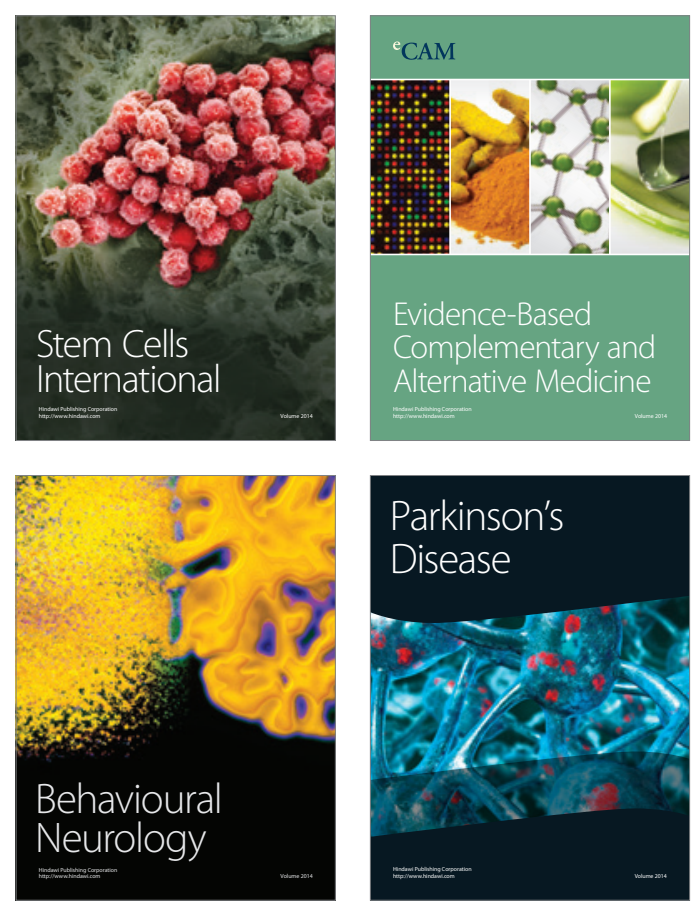

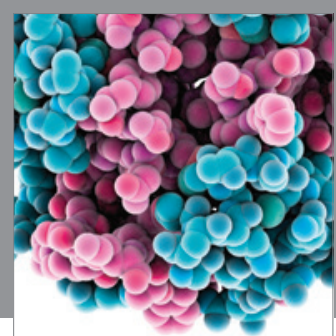

Journal of
Diabetes Research

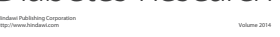

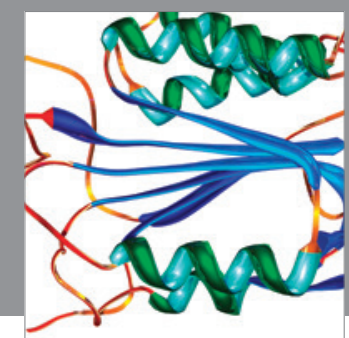

Disease Markers
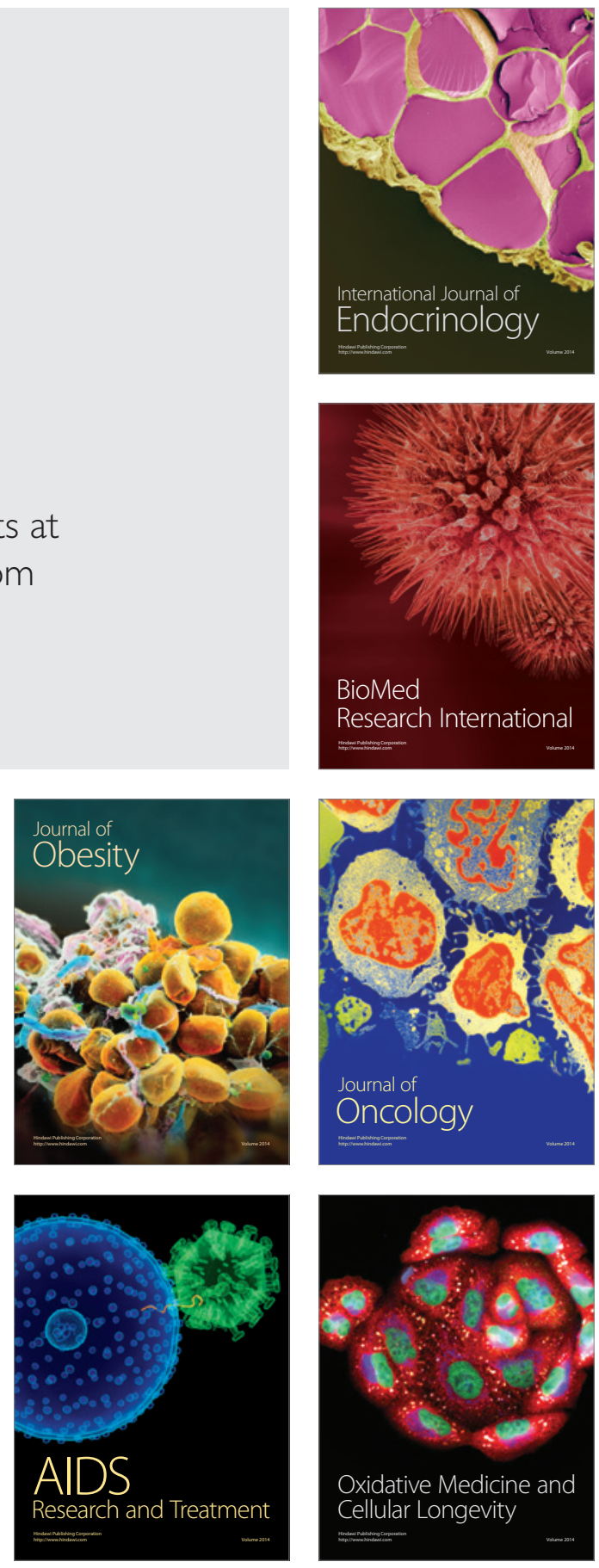